ISSN 1991- 8690

الترقيم الدولي 8690 - 1991

Website: http://jsci.utq.edu.iq

Email: utjsci@utq.edu.iq

\title{
Comparative Study for the Levels of Trace Elements in Water from Southern Part of Iraq during $1996-2010$
}

\author{
Muayad H.Mohammed \\ Dept.of Marine Envir. Chem., Marine Science Centre - Basrah Univ. \\ E-mail: abu_hassan73@yahoo.com
}

\section{Abstract:}

A comparative study for the levels of trace elements in water from southern part of IRAQ for the period of time 1996 to 2010 was carried out to investigate the quality of waters. The study is based on the chemical analysis of trace elements: $\mathrm{Cd}, \mathrm{Co}, \mathrm{Cr}, \mathrm{Cu}, \mathrm{Fe}, \mathrm{Mn}, \mathrm{Ni}, \mathrm{Pb}$ and $\mathrm{Zn}$. For subsurface water samples covered 12 stations along Al-Izz, Tigress, Euphrates, Shatt Al-Arab, Khor Al-Zubair, Shatt Al-Basrah and Main Outlet Drainage (MOD) rivers. Spectrophotometry was adopted for this analysis. The results showed that levels of trace elements were between those for dissolved phase and particular matter of water in region which normally analyzed by atomic spectrometer. Trace elements concentrations reported by this study were higher than allowed levels by WHO and IRPR without any classification of the phase studied. Fluctuation of elements concentrations in the area attributed to metal input as well as geochemical and hydrological characteristics of the water.

\section{Introduction:}

Due to increase industrial, agricultural as well as urbanization activities, pollution could be arises due to waste discharges which altering the quality of water used for domestic purposes. Among pollutants which showed health problems are the trace elements (Lucky et. al., 1975; Mi et. al., 2006; Chen et. al.2007).

The determination of trace elements in water have been reported to be analyzed extensively by atomic absorption spectrometry. On the other hand minor studies were done by anodic stripping voltametry method (Karadakhi et. al., 1987) and spectrophotometry (Al-Imarah et. al., 1996).
Shatt Al-Arab river have given an extensive studies for trace elements and minor ions (Abaychi and Mustafa, 1988; Al-Imarah and Jawad, 1994; Al-Saad, 1995;Al-Khafaji, 1996) and recently few studies are performing for Shatt Al-Basrah and MOD rivers while those for lower reaches of Tigris, Euphrates and Al-Izz river are very rare.

In water analysis, samples are often divided into two fractions with particles smaller and bigger than $0.5 \mu \mathrm{m}$ containing dissolved and suspended elements respectively (Al-Imarah et. $a l ., 1996)$. The aim of this study was to determine the levels of total trace elements distributed in water from southern part of Iraq in order to 
achieve a better understanding of pollutants in this area because water could be consumed directly by human being without treatment at certain studied stations.

\section{SAMPLING AND ANALYSIS:}

The study was carried out on the Southern part of Iraq ( Fig.1) which lies along the most highly agricultural regions in addition to small industrialized estates to the north especially manufacturing of bricks in which refined crude is used as a fuel (Dawood, 1995). In this area the prevailing wind is the Northern which facilitate carriage of polluted dust and smoke towards the south (Yaaqub, 1991).Sub-surface water samples were collected at three periods: July, Sept. and Nov. 2010, from selected stations covering the southern part of IRAQ waterways, which stretches from Misan Governorate to Khor Al-Zubair.
Containers used were acidic prewashed polyethylene bottles of $1 \mathrm{~L}$ volume. Few drops of nitric acid were added as a preservative agent for trace elements analysis (Korkish and Sorio, 1975), and samples were kept in fridge prior to analysis. The contents of trace elements $\mathrm{Cd}, \mathrm{Co}, \mathrm{Cr}, \mathrm{Cu}$, $\mathrm{Fe}, \mathrm{Mn}, \mathrm{Ni}, \mathrm{Pb}$ and $\mathrm{Zn}$ in nonfiltered water samples which defined as total trace elements concentration in ppm were determined according to Hach standard method ( Hach, 1973), in manufactured by Hach company was used throughout this work. To $25-100 \mathrm{ml}$ of water sample a specific reagent analyzed metal was added and the analysis was done after the adjustment of the instrument for the specified wavelength and programmed number.The dissolved solids (TDS) for each sample were measured too by the same instrument.

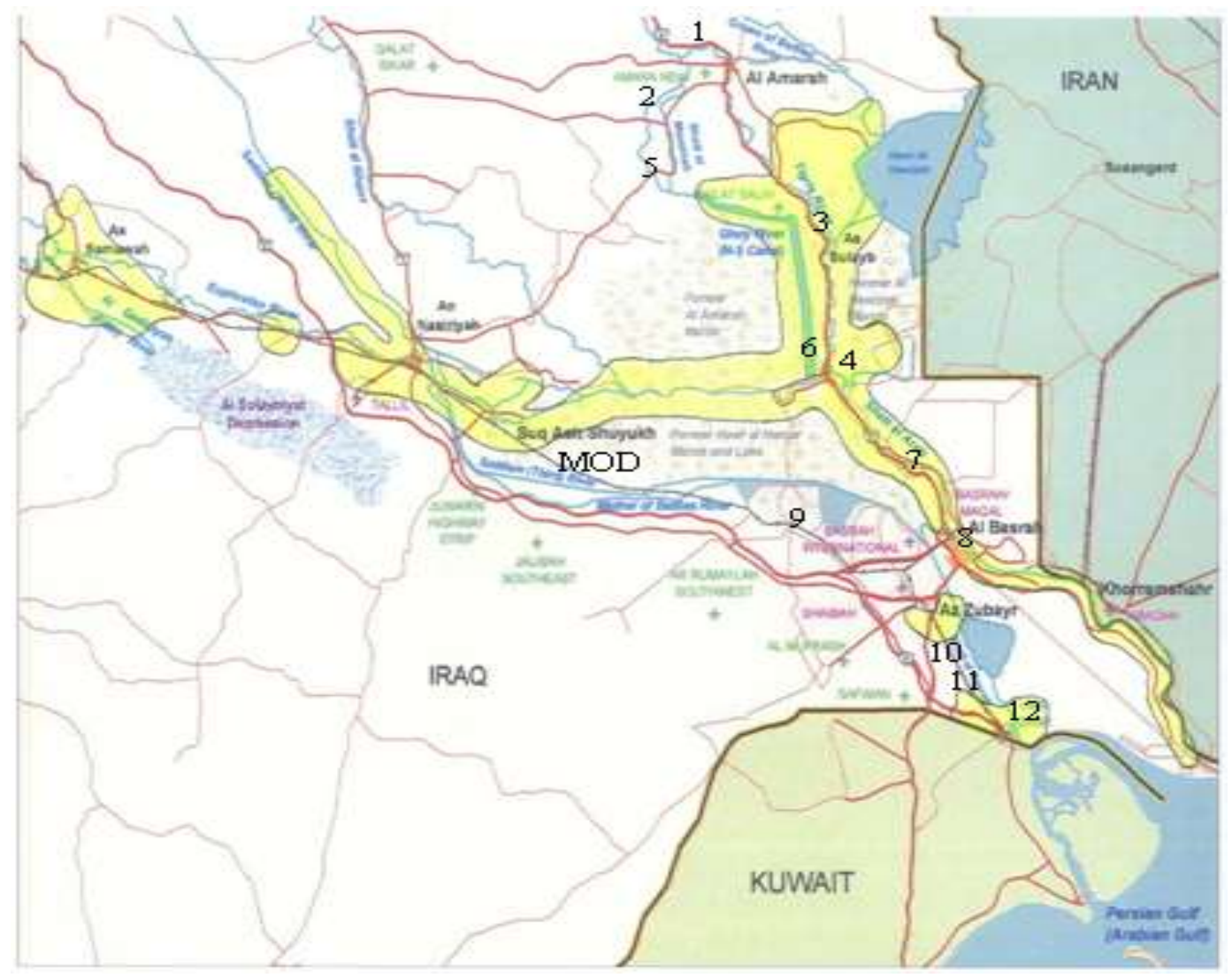

Fig. 1. Location map of the study area showing the sampling stations $(1-12)$. 


\section{RESULTS AND DISCUSSION:}

The stations in this study were classified into two categories, fresh water representing stations 1 - 6, which cover Tigris and Al-Izz rivers and estuarine water representing stations $7-12$, which cover Shatt Al-Arab river, MOD river,
Shatt Al-Basrah and Khor Al-Zubair.Values of trace elements as well as TDS in samples of subsurface water from selected stations at three periods of time, July, Sept. and Nov. 2010 are presented in Table (1).

Table 1. Concentration of trace elements (in ppm) and TDS (in $\mathrm{g} / \mathrm{l}$ ) in water from Southern Iraqi Rivers during the period July - Nov.2010.

\begin{tabular}{|c|c|c|c|c|c|c|c|c|c|c|c|}
\hline Season & Sta. & Cd & Co & $\mathrm{Cr}$ & $\mathbf{C u}$ & $\mathrm{Fe}$ & Mn & Ni & $\mathbf{F b}$ & $\overline{\mathbf{Z n}}$ & TDS \\
\hline \multirow{12}{*}{ 点 } & 1 & 0.090 & 0.020 & 0.620 & 0.290 & 0.070 & 0.110 & 0.430 & 0.170 & 0.006 & 0.740 \\
\hline & 2 & 0.090 & 0.020 & 0.780 & 0.300 & 0.080 & 0.120 & 0.420 & 0.260 & 0.040 & 0.580 \\
\hline & 3 & 0.090 & 0.030 & 0.440 & 0.760 & 0.050 & 0.110 & 0.211 & 0.220 & 0.010 & 0.610 \\
\hline & 4 & 0.198 & 0.040 & 0.250 & 1.420 & 0.060 & 0.130 & 0.300 & 0.410 & 0.032 & 1.240 \\
\hline & 5 & 0.102 & 0.040 & 0.460 & 0.298 & 0.070 & 0.110 & 0.398 & 0.190 & 0.010 & 0.730 \\
\hline & 6 & 0.138 & 0.060 & 0.380 & 0.220 & 0.560 & 0.240 & 0.360 & 0.110 & 0.010 & 0.810 \\
\hline & 7 & 0.144 & 0.050 & 0.290 & 2.850 & 0.060 & 0.260 & 0.387 & 0.280 & 0.040 & 1.450 \\
\hline & 8 & 0.157 & 0.070 & 0.510 & 3.832 & 0.070 & 1.870 & 0.543 & 0.290 & 0.060 & 1.240 \\
\hline & 9 & 0.160 & 0.060 & 0.470 & 0.970 & 0.050 & 0.320 & 0.337 & 0.270 & 0.030 & 2.900 \\
\hline & 10 & 0.138 & 0.110 & 0.410 & 2.300 & 0.060 & 0.510 & 0.342 & 0.290 & 0.020 & 3.670 \\
\hline & 11 & 0.110 & 0.120 & 0.430 & 4.930 & 0.120 & 0.900 & 0.389 & 0.260 & 0.040 & 3.720 \\
\hline & 12 & 0.240 & 0.090 & 0.668 & 8.920 & 0.090 & 0.410 & 0.378 & 0.490 & 0.070 & 11.400 \\
\hline \multirow{12}{*}{ 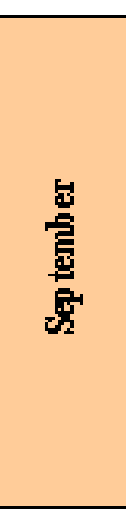 } & & 110 & 0050 & 510 & & 060 & & & & & \\
\hline & $\frac{1}{2}$ & $\frac{0.110}{0.260}$ & $\frac{0.000}{0.050}$ & 0.510 & $\frac{1.0 \% 0}{1.660}$ & $\frac{0.000}{0.020}$ & $\frac{0.210}{0.130}$ & $\frac{0.410}{0.430}$ & $\frac{0.220}{0.540}$ & $\begin{array}{l}0.001 \\
0.042\end{array}$ & $\frac{0.840}{0.850}$ \\
\hline & 3 & 0.130 & 0.040 & 0.550 & 1.520 & 0.030 & 0.200 & 0.210 & 0.330 & 0.022 & 0.890 \\
\hline & 4 & 0.140 & 0.080 & 0.610 & 1.430 & 0.070 & 0.210 & 0.301 & 0.280 & 0.034 & 1.200 \\
\hline & 5 & 0.098 & 0.050 & 0.640 & 1.420 & 0.050 & 0.400 & 0.399 & 0.210 & 0.020 & 0.860 \\
\hline & 6 & 0.176 & 0.050 & 0.790 & 2.760 & 0.160 & 0.600 & 0.380 & 0.200 & 0.009 & 0.980 \\
\hline & 7 & 0.092 & 0.060 & 0.680 & 2.350 & 0.080 & 0.150 & 0.398 & 0.220 & 0.045 & 1.440 \\
\hline & 8 & 0.148 & 0.090 & 0.500 & 2.160 & 0.070 & 0.230 & 0.597 & 0.270 & 0.070 & 1.240 \\
\hline & 9 & 0.180 & 0.110 & 1.560 & 2.040 & 0.180 & 0.100 & 0.348 & 0.310 & 0.060 & 2.990 \\
\hline & 10 & 0.256 & 0.120 & 2.430 & 3.770 & 0.170 & 0.710 & 0.340 & 0.450 & 0.036 & 3.010 \\
\hline & 11 & 0.190 & 0.070 & 1.270 & 3.920 & 0.350 & 0.980 & 0.388 & 0.370 & 0.040 & 3.100 \\
\hline & 12 & 0.102 & 0.070 & 0.980 & 7.610 & 0.050 & 0.310 & 0.381 & 0.280 & 0.070 & 13.890 \\
\hline & & & & & & & & & & & \\
\hline \multirow{12}{*}{ 宽 } & 1 & 0.150 & 0.040 & 1.240 & 0.770 & 0.060 & 0.090 & 0.520 & 0.310 & 0.008 & 0.780 \\
\hline & 2 & 0.155 & 0.050 & 0.720 & 0.890 & 0.030 & ND & 0.520 & 0.370 & 0.050 & 0.770 \\
\hline & 3 & 0.070 & 0.050 & 0.870 & 0540 & 0.030 & 0.080 & 0.189 & 0.180 & 0.020 & 0.770 \\
\hline & 4 & 0.096 & 0.070 & 0.340 & 0.490 & 0.010 & 0.130 & 0.280 & 0.200 & 0.033 & 0.760 \\
\hline & 5 & 0.160 & 0.040 & 0.670 & 0.498 & 0.013 & 0.090 & 0.379 & 0.370 & 0.020 & 0.810 \\
\hline & 6 & 0.162 & 0.041 & 0.230 & 0.685 & 0.010 & 0.220 & ND & 0.165 & 0.010 & 0.990 \\
\hline & 7 & 0.123 & 0.050 & 0.589 & 0.350 & 0.042 & 0.144 & 0.366 & 0.298 & 0.050 & 1.230 \\
\hline & 8 & 0.162 & 0.070 & 0.550 & 1.100 & 0.060 & 0.490 & 0.510 & 0.375 & 0.080 & 1.180 \\
\hline & 9 & 0.091 & 0.090 & 0.810 & 2.640 & 0.040 & 0.230 & 0.290 & 0.203 & ND & 3.870 \\
\hline & 10 & 0.090 & 0.098 & 0.800 & 2.900 & 0.020 & 0.110 & 0.298 & 0.300 & 0.030 & 3.410 \\
\hline & 11 & 0.100 & 0.060 & 0.710 & 2.720 & 0.040 & 0.220 & 0.306 & 0.224 & 0.040 & 3.010 \\
\hline & 12 & 0.110 & 0.070 & 0.540 & 2.340 & 0.120 & 0.110 & 0.340 & 0.320 & 0.090 & 13.890 \\
\hline
\end{tabular}

ND: Not detected. 
According to TDS values which shown in Table (1), the above classification is maintain. The water of stations $1-6$ is soft water in which TDS values recorded were $<1 \mathrm{~g} / 1$, moderate values of TDS in the range of $1-2 \mathrm{~g} / 1$ were recorded for estuarine water of stations 7 and 8 which is slightly saline, while other values of TDS in the range of $2-13 \mathrm{~g} / \mathrm{l}$ which recorded at stations $9-12$ are still represent an estuarine environment of MOD river, Shatt Al-Basrah and Khor Al-Zubair ( Hem, 1970; WHO, 1971).

Water samples were analyzed for trace elements without filtration. Therefore values recorded were for average trace elements which represented by dissolved phase and particulate matter. Filtration by general filter paper did not show any significant differences in trace metal concentrations. This will reflect using water of the same quality, after or before filtration, for different purposes especially for domestic uses.

The results reported in Table (1) during the period of study point to a certain fluctuations in the total concentration of trace elements in water of investigated rivers in southern part of Iraq. Moreover, there were no significant relations between these elements and time at each station. Mean values of individual trace elements in inland waters depend on the relative concentration of metal being weathered in the drainage basin and its hydrological conditions and on the rate of weathering of different minerals containing trace elements in addition to geochemical fractionation in the soil profile (Reczynska-Dutka, 1984), while trace elements fluxes could be explained on the basis of pollution.

$\mathrm{Cu}$ was the highest metal recorded at all stations which increases down stream of Iraqi rivers with maximum values at station 12 of 8.92 and $7.61 \mathrm{mg} / 1$ during July and Sept. respectively, while $\mathrm{Co}$ and $\mathrm{Zn}$ were the lowest in the region with highest values of $0.12 \mathrm{mg} / 1$ at stations 10 and 11 .

The levels of all trace elements at stations 3 and 5 were lower than other stations, due to the agricultural nature of the area and its surroundings.
All studied trace elements showed an increase, as an average, from north to south throughout Iraqi rivers. This behavior could be explained based on increased urbanization and industry, which represented as major sources of different pollutant thrown to the environment.

On an average values, levels of all trace elements recorded were higher in station 8 down stream Basrah city than station 7 upper stream of Basrah city due to waste discharges through Shatt Al-Arab branches. This behavior is shown at station 2 down Misan city in which trace elements were higher to a little extent than at station 1 upper stream Misan city due to discharges from the city as well as waste discharge from brick and vegetable oil production factories (DouAbul et. al., 1987) which are located close to station 2, while station 1 is effected by agricultural lands.

The increase in Ni from MOD river towards Khor Al-Zubair referred to the effect of refinery waste thrown at Shatt Al-Basrah between stations 10 and 12 (Al-Imarah et. al., 2000).

In general, concentrations of studied trace elements as an average values recorded from selected stations are higher than those reported by studies of standard values with the exception of $\mathrm{Zn}$ which was low in concentration. This could be explained by two reasons: this study was conducted spectophotometrically while other studies done by atomic absorption spectrometry, and second, the values recorded in the present study represent the total trace elements in the investigated water samples while others either dissolved or particulate.

The values of trace elements as well as TDS in samples of same locations and time by (Al-Imarah et. al., 2000) are presented in Table (2). The different between current study and the previous study can show in the Table (3). 
Table 2. Concentration of trace elements (in ppm) and TDS (in $\mathrm{g} / \mathrm{L}$ ) in water from Southern Iraqi rivers during the period July - Nov.1996.

( Al-Imarah et al., 2000).

\begin{tabular}{|c|c|c|c|c|c|c|c|c|c|c|c|}
\hline Season & Sta. & Cd & Co & Cr & $\mathbf{C u}$ & $\mathbf{F e}$ & Mn & $\mathrm{Ni}$ & $\mathbf{P b}$ & Zn & TDS \\
\hline \multirow{12}{*}{ 点 } & 1 & 0.080 & - & 0.410 & 0.270 & 0.060 & 0.100 & - & 0.150 & - & 0.700 \\
\hline & 2 & 0.080 & - & 0.660 & 0.280 & 0.060 & 0.100 & - & 0.220 & - & 0.570 \\
\hline & 3 & - & - & - & - & - & - & - & - & - & - \\
\hline & 4 & 0.176 & - & \begin{tabular}{|l}
0.150 \\
\end{tabular} & \begin{tabular}{|l}
1.560 \\
\end{tabular} & 0.050 & 0.100 & - & 0.380 & - & 1.230 \\
\hline & 5 & 0.086 & - & 0.410 & 0.270 & 0.060 & 0.100 & 0.150 & 0.150 & - & 0.700 \\
\hline & 6 & 0.098 & - & 0.320 & $\begin{array}{l}0.170 \\
\end{array}$ & 0.500 & 0.200 & - & 0.090 & - & 0.790 \\
\hline & 7 & 0.104 & - & 0.250 & 2.620 & 0.060 & 0.200 & - & 0.220 & - & 1.220 \\
\hline & 8 & \begin{tabular}{|l}
0.126 \\
\end{tabular} & - & 0460 & 3.590 & 0.060 & 1.600 & - & 0.270 & - & 1.210 \\
\hline & 9 & - & - & - & 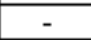 & - & - & - & - & - & - \\
\hline & 10 & \begin{tabular}{|l}
0.120 \\
\end{tabular} & - & \begin{tabular}{|l}
0.370 \\
\end{tabular} & \begin{tabular}{|l}
1.950 \\
\end{tabular} & 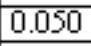 & \begin{tabular}{|l}
0.400 \\
\end{tabular} & - & $\begin{array}{l}0.270 \\
\end{array}$ & - & 3.120 \\
\hline & 11 & 0.100 & - & 0.210 & 4.840 & 0.100 & 0.700 & - & 0.230 & - & 3.100 \\
\hline & 12 & 0.210 & - & 0.560 & 7.940 & 0.080 & 0.300 & - & 0.460 & - & 9.680 \\
\hline & & & & & & & & & & & \\
\hline \multirow{12}{*}{ 昰 } & 1 & 0.090 & - & 0.490 & 1.490 & 0.050 & 0.200 & - & 0.200 & - & 0.820 \\
\hline & 2 & \begin{tabular}{|l}
0.220 \\
\end{tabular} & - & 0.540 & \begin{tabular}{|l}
1.490 \\
\end{tabular} & \begin{tabular}{|l}
0.010 \\
\end{tabular} & \begin{tabular}{|l}
0.100 \\
\end{tabular} & - & 0.500 & - & 0.840 \\
\hline & 3 & - & - & - & - & - & - & - & - & - & - \\
\hline & 4 & 0.114 & - & 0.580 & 1.330 & 0.060 & 0.200 & - & 0.250 & - & 1.030 \\
\hline & 5 & 0.080 & - & 0.620 & 1.390 & 0.040 & 0.400 & - & 0.180 & - & 0.830 \\
\hline & 6 & 0.152 & - & 0.760 & 2.570 & 0.140 & 0.500 & - & 0.150 & - & 0.960 \\
\hline & 7 & 0.074 & - & \begin{tabular}{|l|l|}
0.650 \\
\end{tabular} & \begin{tabular}{|l|}
2.050 \\
\end{tabular} & \begin{tabular}{|l}
0.140 \\
\end{tabular} & \begin{tabular}{|l}
0.100 \\
\end{tabular} & - & \begin{tabular}{|l|l|}
0.160 \\
\end{tabular} & - & 1.410 \\
\hline & 8 & 0.112 & - & 0.470 & \begin{tabular}{|l}
1.950 \\
\end{tabular} & 0.060 & 0.200 & - & 0.240 & - & 1.140 \\
\hline & 9 & - & - & 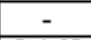 & 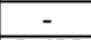 & 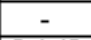 & 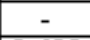 & - & - & - & - \\
\hline & 10 & 0.210 & - & 2.160 & 3.480 & 0.140 & 0.600 & - & 0.420 & - & 2.680 \\
\hline & 11 & 0.160 & - & 1.160 & 3.880 & 0.330 & 0.900 & - & 0.350 & - & 2.560 \\
\hline & 12 & 0.080 & - & 0.700 & $\begin{array}{l}7.160 \\
\end{array}$ & 0.040 & 0.200 & - & 0.200 & - & 12.580 \\
\hline & & & & & & & & & & & \\
\hline \multirow{12}{*}{ 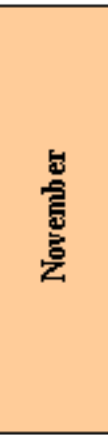 } & 1 & \begin{tabular}{|l|l|}
0.120 \\
\end{tabular} & \begin{tabular}{|l|l|}
0.020 \\
\end{tabular} & \begin{tabular}{|l|l|}
1.180 \\
\end{tabular} & \begin{tabular}{|l|l|}
0.740 \\
\end{tabular} & \begin{tabular}{|l|}
0.050 \\
\end{tabular} & $\mathrm{ND}$ & \begin{tabular}{|l|l|}
0.450 \\
\end{tabular} & \begin{tabular}{|l|}
0.290 \\
\end{tabular} & $\mathrm{ND}$ & 0.740 \\
\hline & 2 & 0.130 & 0.040 & 0.530 & 0.880 & 0.030 & ND & 0.460 & 0.300 & 0.040 & 0.720 \\
\hline & 3 & 0.050 & 0.030 & 0.660 & 0.520 & 0.020 & ND & 0.167 & 0.110 & 0.020 & 0.710 \\
\hline & 4 & 0.078 & 0.040 & 0.220 & 0.480 & ND & 0.100 & 0.238 & 0.170 & 0.030 & 0.710 \\
\hline & 5 & 0.120 & 0.020 & 0.550 & \begin{tabular}{|l}
0.470 \\
\end{tabular} & 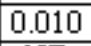 & ND & \begin{tabular}{|l}
0.352 \\
\end{tabular} & 0.290 & \begin{tabular}{|l}
0.010 \\
\end{tabular} & 0.780 \\
\hline & 6 & \begin{tabular}{|l|l|}
0.100 \\
\end{tabular} & \begin{tabular}{|l}
0.020 \\
\end{tabular} & \begin{tabular}{|l}
0.190 \\
\end{tabular} & 0.680 & ND & 0.200 & 0.342 & 0.100 & 0.010 & 0.980 \\
\hline & 7 & \begin{tabular}{|l|l|}
0.104 \\
\end{tabular} & 0.030 & \begin{tabular}{|l|l|}
0.460 \\
\end{tabular} & \begin{tabular}{|l|}
0.350 \\
\end{tabular} & \begin{tabular}{|l}
0.040 \\
\end{tabular} & \begin{tabular}{|l}
0.100 \\
\end{tabular} & \begin{tabular}{|l|l}
0.326 \\
\end{tabular} & \begin{tabular}{|l|l|}
0.260 \\
\end{tabular} & \begin{tabular}{|l}
0.040 \\
\end{tabular} & 1.080 \\
\hline & 8 & 0.136 & 0.060 & 0.440 & \begin{tabular}{|l}
1.050 \\
\end{tabular} & 0.050 & 0.400 & 0.468 & 0.300 & 0.060 & 1.010 \\
\hline & 9 & 0.076 & 0.050 & 0.720 & 2.590 & 0.030 & 0.200 & 0.250 & 0.160 & 0.040 & 3.440 \\
\hline & 10 & 0.070 & 0.080 & 0.680 & 2.840 & ND & 0.100 & 0.260 & 0.200 & 0.030 & 3.020 \\
\hline & 11 & 0.080 & 0.040 & 0.530 & 2.650 & ND & 0.200 & 0.280 & 0.180 & 0.030 & 2.730 \\
\hline & 12 & 0.090 & 0.040 & 0.460 & 2.330 & 0.100 & ND & 0.310 & 0.270 & 0.080 & 11.800 \\
\hline
\end{tabular}

ND: Not detected. 
Table 3. The different of trace elements (in ppm) and TDS (in $g / L$ ) between current study and (Al-Imarah et al., 2000).

\begin{tabular}{|c|c|c|c|c|c|c|c|c|c|c|c|}
\hline Season & Year & $\mathrm{Cd}$ & Co & $\mathrm{Cr}$ & $\mathrm{Cu}$ & $\mathrm{Fe}$ & $\mathrm{Mn}$ & $\mathrm{Ni}$ & $\mathrm{Pb}$ & $\mathrm{Zn}$ & TDS \\
\hline \multirow{2}{*}{ July } & 2010 & $0.000-0240$ & $0.020-0.120$ & $0.250-0.780$ & $0.220-8920$ & $0.070-0.120$ & $0.110-1870$ & $0.211-0.543$ & $0.110-0.490$ & $0.010-0070$ & $0.580-11.40$ \\
\hline & 1996 & $0.080-0.120$ & - & $0.150-0560$ & $0.170-7940$ & $0.050-0.100$ & $0.100-0.160$ & - & $0.090-0.460$ & - & $0.570-9.680$ \\
\hline \multirow{2}{*}{ Sept. } & 2010 & $0.092-0260$ & $0.040-0.120$ & $0.510-2.430$ & $1.420-7.610$ & $0.020-0350$ & $0.100-0980$ & $0.210-0597$ & $0.200-0.540$ & $0.007-0.070$ & $0.840-13.89$ \\
\hline & 1996 & 0.0740 .160 & - & $0.470-2.160$ & $1.490-7.160$ & $0.040-0330$ & $0.100-0900$ & - & $0.150-0350$ & - & $0.820-12.580$ \\
\hline \multirow{2}{*}{ Nov. } & 2010 & $0.070-0.162$ & $0.040-0980$ & $0.230-1240$ & $0.490-2900$ & $0.010-0.120$ & $0.080-0.490$ & $0.189-0520$ & $0.165-0375$ & $0.008-0.090$ & $0.770-13.890$ \\
\hline & 1996 & $0.078-0.136$ & $0.020-0080$ & $0.0 .190-1.180$ & $0.470-2840$ & $0.010-0.050$ & $0.100-0.400$ & $0.167-0.468$ & $0.100-0300$ & $0.010-008$ & $0.710-11.800$ \\
\hline
\end{tabular}

Table (3) shows the difference between current study and previous study (Table 2), which seems high concentrations of trace elements measured and high values of TDS in all stations. This could be explained by several reasons: increased environmental pollution in those areas and the climate change in the world and also Shatt Al-Arab water affected by operation of load and transport and discharge of oil as well as waste that has thrown during transportation of waters which represent a source of contaminate of trace elements due to oil contents to certain ratios of these elements and increasing levels of pollution of these materials in the case of non-application of safety requirements and protect the environment from the leaking of oil or using the wrong directions in dealing with oil or any of its derivatives (Al-Saad et. al.,1997).

\section{References:}

Abaychi, J.K. and Mustafa, Y.Z. 1988. The Asiatic Clam, Cocbicula fluminea: An indicator of trace metals pollution in the Shatt Al-Arab river, Iraq. Environ. Poll., 54:109-122.

Al-Imarah, F.J.M., Al-Timari, A.A and Al-Edani, T.E.J. 1996. Trace metals in core sediments from
NW Arabian Gula. Marine Mesopotamica, 11(1): $1-15$.

Al-Imarah, F.J.M., Ghadban, R.A. and Al-Shaway, S.F. 2000. Levels of trace metals in water from southern part of Iraq. Marine Mesopotamica, 15(2): $365-372$.

Al-Imarah, F.J.M. and Jawad, AM. 1994. Physicochemical parameters of southern Iraqi water, NW Arabian Gulf. Marine Mesopotamica, 9(1): 1- 12.

Al-Khafaji, B.Y. 1996. Trace metals in water, sediments and fishes from Shatt Al-Arab estuary, NW Arabian Gulf. Ph.D. Thesis, University of Basrah, Basrah.

Al-Saad, H,T. 1995. Distribution and sources of hydrocarbons in Shatt Al-Arab estuary and NW Arabian Gulf. Ph.D. Thesis, University of Basrah, Basrah.

Al-Saad,H.T., Mustafa,Y.Z. and Al-Imarah,F.J. 1997. Distribution of trace metals on the tissues of fish from Shatt Al-Arab estuary, IRAQ. Mar. Mesopot., 15(1): 145-156.

Chen,C.W., Kao,C.M. and Dong,C.D. 2007. Distribution and accumulation of heavy metals in the sediments of Kaohsiung Harbor, Taiwan. Chemosphere, 66: 1431-1440.

Dawood, S.M. 1995. Study of pollutants emission from brick factories in southern Iraq. M.Sc. Thesis, University of Basrah, Basrah. 
DoyAbul, A.A.Z., Abaychi, J.K., Al-ssadi, M.K. and Al-Awadi, H. 1987. Restoration of heavily polluted branches of the Shatt Al-Arab river, Iraq. Water Res., 21: 955 - 960.

Hach, 1973. "Water Analysis Handbook", Hach chemical Company, Iowa, USA.

Hem, J.D. 1970. "Study and Interpretation of the chemical characteristics of natural water", US Geol. For Water Supply, paper 1473.

Karadkhi, T.M., A.A.,Amer N.M.,Abou-Donia M.A and Khatab N. 1987. Determination of traces of $\mathrm{Zn}, \mathrm{Cd}, \mathrm{Pb}$, and $\mathrm{Cu}$ in white suger. Talanta, 34 : $995-999$.

Korkish, J. and Sorio, A. 1975. Preservation agent for trace metals analysis. Anal. Chim. Acta, 76: $393-$ 396.

Lucky, T.D., Venugapal, B. and Hutcheson, D. 1975. "Heavy Metal Toxicity, Safety and Harmalogy,
Environmental Qaulity and Safety Supptement". Vol. 1, 119pp, Academic Press NewYork.

Mi,J., Li,Y., Zhou,X., Zheng,B. and Zhou,Y. 2006. Simultaneous determination of iron, copper and cobalt in food samples by CCD-diode Array detection-flow injection analysis with partial least squares calibration model, J. Phy.:Conf.ser.28:6669.

Reczynska-Dutka, M. 1984. Snow pollution and its effect on heavy elements load of the Kozlowa Gora resrvior as compared to rain and river water. Polskie Arch. Hydrobiol., 31: 163- 173.

WHO, 1971. " International standards for Drinking water" $3^{\text {rd }}$ ed., Geneva.

Yaaqub, R.R. 1991. Air pollution transport and effects: A case study of the weather during the war. Oceanography of Khor Al-Zubair, 3: $75-85$.

$$
\begin{aligned}
& \text { در اسة مقارنة لمستويات المعادن النزرة في مياه أنهار جنوب العر اق مابين } 1996 \text { - } 2010 \\
& \text { مؤيد حسن محمد } \\
& \text { قسم الكيمياء البيئية البحرية - مركز علوم البحار - جامعة البصرة } \\
& \text { البريد الاليكتروني: abu_hassan73@yahoo.com }
\end{aligned}
$$

المستخلص:

$$
\begin{aligned}
& \text { أجريت دراسـة مقارنة لتقيم نوعيـة مياه انهار جنوب العراق للفترة الممتدة بين } 1996 \text { و } 2010 \text { حيث اعتمدت الدراسـة على } \\
& \text { التحليل الكيميائي للمعادن النزرة: الكادميوم والكوبلت والكروم والنحاس والحديد والنيكل والرصـاص والخارصين لعينات مياه تحت } \\
& \text { السطحية غطت } 12 \text { محطة خـلال أنهار دجلة والفرات والعز وشط العرب وقناة التصريف الرئيسي وخور الزبير وذلك باستخدام } \\
& \text { الطرق الطيفية في التحليل. أظهرت النتائج أن مستويات المعادن النزرة كانت أعلى بكثير من الفترة السـابقة وهي بين الطورين } \\
& \text { الذائب والعالق والتي غالبا ما تحدد باستخدام مطيافية الامتصاص الذري والتي كانت أعلى من المستويات المسموح بها من قبل } \\
& \text { منظمة الصحة العالمية ونظام حماية الأنهار العراقية بدون تحديد الطور المعين. ويعزى سبب التذبذب في نركيز المعادن النزرة في } \\
& \text { المنطقة إلى ما يضاف منها نتيجة للعمليات المختلفة إضافة إلى المميزات الهيدرولوجية والجيوكيميائية للمياه. }
\end{aligned}
$$

